\title{
PIG BITE IN BRAZIL: A CASE SERIES FROM A TEACHING HOSPITAL
}

\author{
Sérgio de Andrade Nishioka, Suzana Terumi Handa and Raquel Souza Nunes
}

\begin{abstract}
A retrospective survey done from 1987 till 1990 revealed that 23 patients bitten by pigs songht medical help at a teaching hospital in Uberlândia, in southeastern Brazil. Most cases (21) were from Uberlândia. The cases were evenly distributed by month and by year; most of them $(14 / 16 ; 87.5 \%)$ occurred between $7.00 \mathrm{a} . \mathrm{m}$. and $7.00 \mathrm{p} . \mathrm{m}$. The male to female ratio was 6.7:1. Age ranged from 6 to 73 (mean $38.95 \pm S D 22.06$, median 36). The bites were more common on the upper limbs, particularly on the forearms. In 11(47.8\%) cases the injury was described as deep. In most cases where information was available the injury was related to capture, transport or immobilisation of the pig for slaughter. The following medical procedures were performed: local cleansing in $19(82.6 \%)$ cases, rabies vaccine $(12 ; 52.2 \%)$, antirabies serum $(2 ; 8.7 \%)$, suturing $(6 ; 26.1 \%)$ and tetanus vaccine $(12 ; 52.2 \%)$. There was no case of infection at the bite site, neither of rabies or tetanus. By our data, the annual incidence of pig bite in Uberlândia can be estimated to be about 1.5/100.000.
\end{abstract}

Key-words. Bites. Injuries. Rabies. Swine.

Little has been published in the literature on injuries caused by swine in man. Barss \& Ennis $^{2}$ reviewed 20 cases seen at a reference hospital in Papua New Guinea, where $65 \%$ of the patients were bitten or gored by feral pigs. Provoked and unprovoked injuries by domestic pigs have been reported both in developed ${ }^{1711}$ and developing countries $^{8}$. Most of these studies are case reports of surgical aspects and infectious complications, with little emphasis on epidemiological aspects.

We report a retrospective survey of cases of pig bite seen in four years at a teaching hospital in southeastern Brazil. We know of no study on pig bite carried out previously in Brazil.

\section{MATERIAL AND METHODS}

The medical records of patients bitten by pigs who sought medical help at the teaching hospital of the Federal University of Uberlândia, in southeastern Brazil, from 1987 to 1990 were surveyed retrospectively. The distribution of the cases in time and space, by age, sex, clinical findings and treatment measures were recorded. Attempts to

\footnotetext{
Centro de Ciências Biomédicas, Universidade Federal de Uberlândia, Uberlândia, MG, Brasil.

Address to: Dr. Sérgio de Andrade Nishioka. Av. Teresina 1415. Umuarama, 38405-384 Uberlândia, MG, Brasil.

Recebido para publicaçāo em $28 / 10 / 93$.
}

obtain more detailed information were made by visiting the households of the patients living in urban Uberlândia and interviewing them or their relatives. This was achieved for 7 cases.

\section{RESULTS}

Among the 23 patients victims of pig bite attended in the 4-year study period, 21 were from Uberlândia. The cases were evenly distributed by month and by year; most of them $(14 / 16 ; 87.5 \%)$ occurred between $7.00 \mathrm{a} . \mathrm{m}$. and $7.00 \mathrm{p} . \mathrm{m}$. The male to female ratio was 6.7 to 1 . Age ranged from 6 to 73 years, with a mean of $38.95 \pm$ SD 22.06 and a median of 36 (Figure 1). The bites were more common in the upper than in the lower limbs, and most of them were on the forearms (Table 1). The injury was described as deep (as opposed to superficial) in 12 out of the 23 cases.

Information on activity of the victim at the time of the injury was available for only 9 cases, and in 7 of them it was related to capture, transport or immobilisation of the pig for slaughter. In one case the victim was cleaning the pigpen and in another a child was "playing" with the pig. Among the 7 victims interviewed lately, all informed that the pigs belonged to them, their neighbours or employer, and 5 referred that the pigs were raised in pens. Two of the interviewed patients had a past history of pig 
Nishioka SA, Handa ST, Nunes RS. Pig bite in Brazil: a case series from a teaching hospital. Revista da Sociedade Brasileira de Medicina Tropical 27:15-18, jan-mar, 1994.

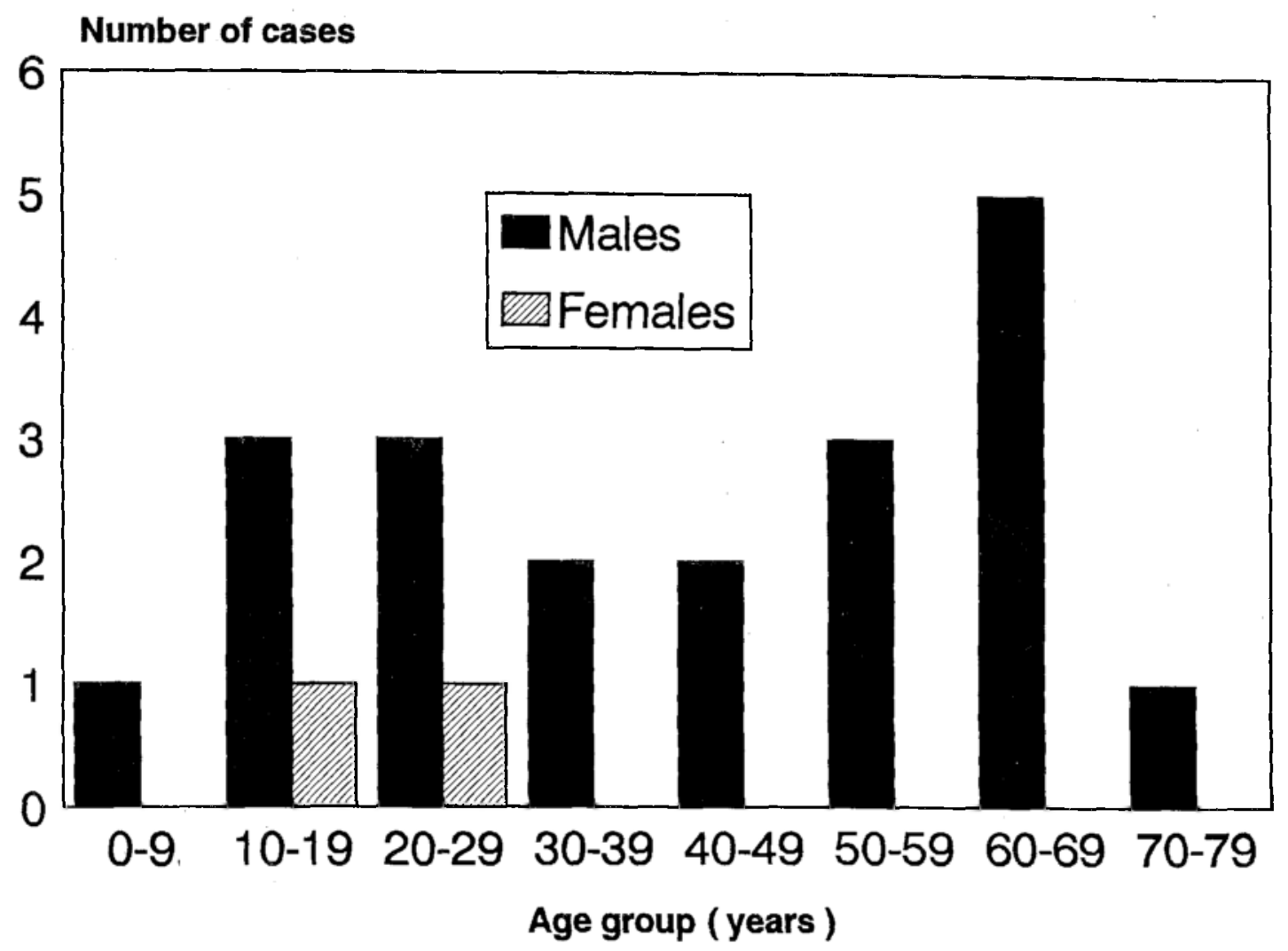

Figure 1 - Age and sex distribuition of 23 cases of pig bite (information on age is not available for one woman).

Table 1- Distribution of the cases of bite attending the teaching hospital (Uberlândia, 1987-1990), by site of the bite*.

\begin{tabular}{crr}
\hline Site of the bite & $\mathrm{N}^{\circ}$ & $\%$ \\
\hline Upper limb (subtotal) & 16 & 61.5 \\
finger & 3 & 11.5 \\
hand & 1 & 3.8 \\
forearm & 10 & 38.5 \\
arm & 1 & 3.8 \\
unspecified & 1 & 3.8 \\
Lower limb (subtotal) & 8 & 30.8 \\
foot & 1 & 3.8 \\
leg & 3 & 11.5 \\
knee & 1 & 3.8 \\
thigh & 3 & 11.5 \\
Unspecified & 2 & 7.7 \\
\hline
\end{tabular}

* One patient was bitten on 2 and another on 3 different sites bite.

The following procedures carried out for treatment of the patients were cited in the reviewed charts: local cleansing (19; $82.6 \%$ cases), rabies vaccine $(12 ; 52.2 \%)$, antirabies serum $(2 ; 8.7 \%)$, suturing $(6 ; 26.1 \%)$ and tetanus vaccine $(12 ; 52.2 \%)$.

No patient referred infection of the bite site. There was also no case of rabies or tetanus in the victims of pig bite.

\section{DISCUSSION}

Raising pigs is an important economic activity in many parts of the world. For instance, there are estimates of more than 55 million pigs in the United States $^{7}$, and 33 million in Brazil ${ }^{4}$. An unknown number is raised for food or as a complementary source of income by poor people, particularly in rural areas but also in suburbs of towns and cities of 
Nishioka SA, Handa ST, Nunes RS. Pig bite in Brazil: a case series from a teaching hospital. Revista da Sociedade Brasileira de Medicina Tropical 27:15-18, jan-mar, 1994.

developing countries. There, pigs are frequently raised without pigpens, and sometimes have free access into the home ${ }^{8}$. Whether this increases the risk of diseases associated with poor hygiene, it also creates opportunities for bites in man. Particularly children with food or food remnants in their hands and face are at risk of being injured by hungry unpenned pigs $^{2} 8$.

Another group at risk of pig bite are adults who raise pigs domestically or who are in contact with these animals occupationally, like abattoir workers. Although we could interview only a fraction of our patients, most of them were bitten when catching, carrying or immobilising pigs, practices related to domestic slaughtering, carried out by people relying mostly on their experience to prevent bites. These activities are ascribed preferentially to men, as can be shown by the high male to female ratio in this series. Slaughtering in abattoirs is theoretically safer, as the employees have less direct contact with the swine.

It was an interesting finding the fact that the forearms were the most common site of bite, probably because these are the most exposed area when one is trying to immobilise a pig. Although most of our patients referred deep wounds, which is confirmed by the fact that in more than $25 \%$ of them suturing was required, their recovery was uneventful. Pig bites have been associated with severe lesions, but that particularly in children and victims of feral pigs ${ }^{2}{ }^{8}$. From the literature, infection of the bite site should be an expected complication of injuries caused by pigs, because the mouths of these animals, particularly the unpenned ones, are heavily contaminated. Infections by haemolytic streptococci, Pasteurella, Bacteroides, Proteus, E. coli $^{1}$ and Flavobacterium ${ }^{7}$ have been described. The absence of infection in our patients is somewhat surprising, and can be explained mainly because of adequate irrigition and care of the wound. Our finding does not support the routine use of prophylactic antimicrobials following pig bite, as suggested by Barnham1.

Human rabies is endemic in Brazil, where an average of 83 cases were reported annually from 1980 to 1991 to the Ministry of Health ${ }^{5}$. Rabies in pigs is not commonly reported, but rabid swine in the excitatory phase may bite other pigs, animals and $\operatorname{man}^{39}$. The policy of the Brazilian Ministry of Health is to give rabies vaccine and antirabies serum as prophlaxis following bites in man of all mammals except dogs, cats and non-selvatic rodents, for whom there are specific recommendations ${ }^{10}$. According to these recommendations, all our patients should have received the rabies vaccine and antirabies serum, and that was not done possibly beciim. not all physicians were informed about the possible association of pig bite and rabies. Post exposure prophylaxis is debatable if the aggressor pig has no clinical evidence of rabies and can be observed, because of the already mentioned fact that rabies in swine is rare. Suturing should be avoided or delayed ${ }^{6}$ 12 , but it is sometimes necessary depending on the site and size of the wound.

Tetanus is another possible complication of injuries caused by pigs, as the contaminated wounds can be the portal of entry for Clostridium tetani spores. Many patients from this study did not receive tetanus prophlaxis, but we are unable to say why because we lack information about their previous immunization status. Nevertheless, physicians facing victims of animal bite have a good opportunity to check their patients' immunization status and to offer them tetanus or the other vaccines they need.

From our data, assuming that all the victims of pig bite of the town were seen at the teaching hospital, the annual incidence of pig bite in Uberlândia can be estimated to be about 1.5 / 100,000 . If we could extrapolate this figure for the country, that would give us more than 2,000 cases per year in Brazil, which certainly is a conservative estimate as many victims do not seek medical assistance. Although it is certainly not a priority in public health, more attention should be give in Brazil and other countries to the adequate registration of cases of pig bite in humans and guidelines for its management should be developed. In developing countries people are likely to continue to raise and slaughter pigs in their backyards; studies on the technique of slaughtering in these settings and conditions should be carried out to assess the risks and determine the safest procedures to be performed, aiming at providing an effective orientation for the prevention of pig bite during slaughter. 
Nishioka SA, Handa ST, Nunes RS. Pig bite in Brazil: a case series from a teaching hospital. Revista da Sociedade Brasileira de Medicina Tropical 27:15-18, jan-mar, 1994.

\section{RESUMO}

Um levantamento retrospectivo revelou que 23 pacientes vítimas de mordida de porco procuraram assistência médica num hospital-escola em Uberlândia, Brasil, de 1987 a 1990. A maioria dos pacientes (21) procedia de Uberlândia. Os casos foram distribuídos uniformemente por mês e ano; a maioria deles (14/16; 87,5\%) ocorreu entre às 7 e às 19 horas. $A$ razão homem.mulher foide 6,7:1. A idade dos pacientes variou de 6 a 73 anos (média: 38,95 土DP 22,06), mediana 36. As mordidas foram mais comuns nos membros superiores, particularmente nos antebraços. Em 11(47,8\%) casos o ferimento foi descrito como profundo. Na maioria dos casos em que houve informação disponivel, o ferimento foi relacionado com captura, transporte ou imobilização do suino para abate. Os seguintes procedimentos médicos foram realizados: lavagem local em 19(82,6\%) casos, vacina anti-rábica (12; 52,2\%), soro anti-rábico (2; $8,7 \%)$, sutura $(6 ; 26,1 \%)$, e vacina antitetânica (12; 52,2\%). Pelos nossos dados, a incidência anual de mordedura de porco em Uberlândia pode ser estimada em 1,5/100.000 habitantes.

Palavras-chaves:Lesões. Mordidas. Raiva. Suinos.

\section{REFERENCES}

1. Barnham M. Pig bite injuries and infection: report of seven human cases. Epidemiology and Infection 101:641-645, 1988.

2. Barss $P$, Ennis S. Injuries caused by pigs in Papua New Guinea. Medical Journal of Australia 149:649$656,1988$.
3. Beran GW. Rabies and infections by rabies-related viruses. In: Beran GW (ed) CRC Handbook Series in Zoonoses. Section B: Viral Zoonoses, Vol. 11. CRC Press, Boca Raton p.57-135, 1981.

4. Bertolin A. Suínos. Lítero-Técnica, Curitiba p.12, 1992.

5. Centro Nacional de Epidemiologia/Ministério da Saúde. Séries históricas de agravos e doenças transmissíveis. Informe Epidemiológico do SUS 1:55, 1992.

6. Chin J, Constantine DG. Rabies. In: Last JM (ed) Maxcy-Rosenau Public Health and Preventive Medicine. Appleton-Century-Crofts, Norwalk p.391397, 1986.

7. Goldstein EJC, Citron DM, Merkin E, Pickett MJ. Recovery of an unusual Flavobacterium group IIblike isolate from a hand infection following pig bite. Journal of Clinical Microbiology 28:1079-1081, 1990.

8. Metlich MA, Acosta JJ, Toranzo M. Reconstruction of the lower lip following pig bites: report of two cases. Journal of Oral Maxillofacial Surgery 44:478$482,1986$.

9. Mohaniy SB, Dutta SK. Veterinary Virology. Lea \& Febiger, Philadelphia p.220, 1981.

10. Secretaria de Estado da Saúde de Minas Gerais. Manual de raiva. Belo Horizonte, 1989.

11. Van Demark RE Sr, Van Demark Jr RE. Swine bites of the hand. Journal of Hand Surgery 16A:136-138, 1991.

12. Warrell DA, Rhabdoviruses: rabies and rabiesrelated viruses. $n$ : Watherall DJ, Ledingham JGG, Warrell DA (eds) Oxoford Textbook of Medicine. Oxford University Press, Oxford p.5105-5114, 1987. 